\title{
The Use of Biochemical Responses for Detecting the Impact of Gas Pollutant on Vigna sinensis L.
}

\author{
Mohammed AbdulRahman Al-Muwayhi \\ Department of Physics and Chemistry, Faculty of Science, Shaqra University \\ P.O. Box 33, Shaqra, 11961, Kingdom of Saudi Arabia
}

Tel: 96-650-440-3171Ｅ-mail: hozim22@hotmail.com

Received: April 12, 2014

doi:10.5296/emsd.v3i1.5462
Accepted: April 21, 2014

URL: http://dx.doi.org/10.5296/emsd.v3i1.5462

\begin{abstract}
Gaseous air pollutants in the troposphere, which is formed in the air under the influence of sunlight and lightning if the air contains nitrogen dioxide or sulfur dioxide even if at low concentrations. Conducted study the effect of gaseous air pollutants emitted by industrial city in Jeddah to evaluate the response of protein and fatty contents in plant Vigna sinensis L. and transplanted at distances $(1-5,500,1000,1500,2000$ meters) from industrial city, has been planting the seeds of the plant Vigna sinensis L. In the uncontaminated region far from industrial city, where we put three pots at each site contains five seeds, and has agriculture in the January 9, 2013, and left until the completion of the initial growth of leaves and then transported to the site of the study. The results showed that the concentrations of polluting gases around industrial city is going up during the study period, reaching $82 \mathrm{ppb}$ for ozone and sulfur dioxide reached $28 \mathrm{ppb}$ while the nitrogen dioxide recorded $35 \mathrm{ppb}$. The results also showed that there is a significant effect of these pollutants on protein content and fatty content ranging in plant leaves for protein $(4.11 \%)$ at a distance $1-5$ meters, and $(4.40 \%)$ at a distance of 2000 meters. The fat content in experimented leaves lied between fat $(3.13 \%)$ at a distance and 1-5 meters $(4.40 \%)$ at the distance of 2000 meters.
\end{abstract}

Keywords: gas pollutants, Vigna sinensis L., protein, fats. Industrial city.

\section{Introduction}

Global mean concentrations of $\mathrm{O}_{3}$ have increased from a pre-industrial level of $10 \mathrm{ppb}$ to about $50 \mathrm{ppb}$ in 2000, and is predicted to reach up to $80 \mathrm{ppb}$ by 2100 (Prather et al. 2001). Most of this increase was driven by nearly three-fold increase in NOx and CO emissions (Prather et al. 2001). In the last few decades, peak $\mathrm{O}_{3}$ concentrations have declined in North America and Europe (Ashmore 2005) due to reductions in precursor emissions. However, over the same period, anthropogenic emissions of $\mathrm{O}_{3}$ precursors across Asia have increased 
(Ohara et al. 2007). Tropical regions are more prone to increasing $\mathrm{O}_{3}$ concentrations due to climatic conditions of these regions which favor $\mathrm{O}_{3}$ formation (Tiwari et al. 2008). It has been established that $\mathrm{O}_{3}$ causes a wide range of detrimental effects on the metabolic processes in horticultural species such as The ozone gas is consider as one of the oxidizing pumpkin (Castagna et al. 2001), sugar beet and rape (Kollner and Krause 2003), lettuce (Calatayud et al. 2002), potato (Pleijel et al. 2004), and tobacco (Degl'Innocenti et al. 2002). Plants may experience $\mathrm{O}_{3}$ damage by physiological dysfunction that occurs before or without the appearance of visible symptoms (Nussbaum et al. 2001; Guidi et al. 2002). Physiological measurements are more reliable to assess intrinsic $\mathrm{O}_{3}$ damage to plants, especially because they can occur earlier in time and at lower $\mathrm{O}_{3}$ fluxes than that required for the appearance of visible $\mathrm{O}_{3}$ injury symptoms (Nussbaum et al. 2001). $\mathrm{O}_{3}$ is a highly reactive molecule which induces formation of reactive oxygen species (ROS), including hydrogen peroxide $\left(\mathrm{H}_{2} \mathrm{O}_{2}\right)$, superoxide $(\mathrm{O}-2)$, and hydroxyl $(\mathrm{OH} \cdot)$ radicals and singlet oxygen in plants (Pasqualini et al. 2002).

The apoplastic matrix is the first compartment of mesophyll cells through which the pollutant has to pass before reaching the symplastic components. The apoplastic components react with $\mathrm{O}_{3}$ and its derived species within the wall space protecting the next level of organization (membranes) from injury. Depletion of antioxidants or a rapid entry of $\mathrm{O}_{3}$ will lessen any protection and will lead to membrane level injury (Conklin and Barth 2004). Any change in the membrane generally leads to some sort of membrane leakage or shifts in signal transduction proteins within the membrane (Cerena et al. 2006) leading to shift in ion concentrations (Klusener et al. 2002) or triggering of a protein cascade, forming new proteins via transcription factor activation (Evans et al. 2005).

The air pollution problems that affect the environmental aspects and the industry has taken a dangerous trend in the great diversity of industries in the field of complex accompanied by often pollution usually results in deterioration of the biosphere in the ecosystem (Janik 1985). The ozone gas is produced from oxidizing gaseous air pollutants in the troposphere which is formed in the air under the influence of sunlight and lightning if the air contains nitrogen dioxide or sulfur dioxide concentrations were even a few (Sandermann et al. 1998). The impact of air pollution on plants through poisoning specific parts of the plant tissue due to the absorption of the leaves of these toxic substances or as a result of chemical reactions to these substances on the surface of the contaminated plant parts. (Febrile et al. 1999).

Introduces ozone into the plant through the stomata where disintegrates in water cell wall and then interacts directly with the plasma membrane through the decomposition process (Ozonolysis) or turns into a form of oxygen active that interact with the plasma membrane and amino acids target proteins of the cell membrane, in addition to materials metabolic existing in the cell wall. These interactions change cellular components may lead to acceleration of aging or cell death (Logan and Naidu, 2002).

The (Plessl et al. 2007) studied the effect of increasing the concentration of ozone on the fat and protein in the leaves and tubers potato plant Solanum tuberosum L. which resulted in the increase of the ozone decrease in the content of protein and fat in the leaves. (Agrawalet al. 
2005) found Low protein content (9.8\%) at 64-69 ppb ozone, (Brunschon-Harti et al. 1995) also found results in similar plant beans, Phaseolus vulgaris L. According to (Cross et al. 1998) that ozone damage proteins and lipids in the cell membrane. In another interpretation found that cracks or oxygen free radicals generated by the interaction of ozone after entering the cell responsible for stimulating the production of compounds such as ethylene, which works as signals or stimuli pay the nucleus to accelerate the aging of the cell and appears in reducing proteins (Pell et al. 1997). Confirmed (Moldau 1999) that the forms of active oxygen that can break down proteins and fats. The study aims to identify the concentrations of some air pollutants (ozone, sulfur dioxide, and the nitrogen dioxide) emitted from industrial city in Jeddah and estimate their adverse effects on the protein content and fatty plant Vigna sinensis L. And transplanted at distances (1-5, 500,1000,1500,2000 meters) from industrial city.

\section{Materials and Methods}

\subsection{Site under Study}

Industrial city in Jeddah city was selected for the current study and select five distances in the direction of the wind far from industrial city, according to the following $(1-5,500,1000$, 1500,2000 meters)

\subsection{Work Steps}

\section{Agriculture:}

Planted seeds (Vigna sinensis L.) outdoors in plastic pots (size $20 \mathrm{~cm}$ ) in silty sandy soil rate (1:1) sterilized by pesticide for the prevention of fungi, where they were put three pots for each distance $(1-5,500,1000,1500,2000$ meters) each pots have of five seeds, and has agriculture in 9th January 2013, and left until the completion of the initial growth of leaves and then transferred to the study site.

\subsection{Measurements}

-Samples were taken from leaves plant (Vigna sinensis L.) in the late vegetative growth before flowering.

-Measurement of the concentration of air pollutants daily in industrial city for the duration of agriculture, by using the device (AEROQUAL Series Monitor with multy head) and was calculated as the average monthly readings.

\subsection{Protein Content Estimation}

Total protein was estimated on the basis of what they contain nitrogen from the sample using the method of Microkeldal. By multiplying the total protein content of total nitrogen in 6.25 (Jones 1991).

\subsection{Fat Content Estimation}

Fat was estimated according to the method contained in the standard Saudi Arabia (1982) No. 547 using a device extraction (Soxhelt). 


\section{Macrothink}

\section{Results}

First measurements of the concentrations of air polluting gases (ozone, sulfur dioxide and nitrogen dioxide) in industrial city:

Results shown in Table (1) that the concentrations of air polluting gases (ozone, sulfur dioxide, and the nitrogen- dioxide) emitted from industrial city on the rise during the study period, where it was noted that the concentrations of ozone and sulfur dioxide and nitrogen dioxide at (2000 meters ) less than when it was at the distances (1-5, 500, 1000.1500 meters ). Where the ozone concentration at the distance (2000 meters ) during the month of April ppb 61 , and at distances $(1-5,500,1000,1500$ meters ) 82, 74, 69, $65 \mathrm{ppb}$, respectively, and the concentration of sulfur dioxide at the distance (2000 meters ) during the month of April ppb 22 , and at distances (1-5, 500, 1000,1500 meters ) 28, 27, 25, 25ppb respectively. concentration of nitrogen dioxide at the distance (2000 meters ) during the month of April ppb 28, and at distances (1-5, 500, 1000,1500 meters ) 35, 34, 32, 29 ppb, respectively. As shown in table (4). The correlation of ozone exposure level with plant fats and protein was significantly correlated reversely which prevail the impacts of ozone oxidizing in reducing the protein and fats content in studied plant especially in the distances near to air pollution source. Sulfur dioxide and nitrogen dioxide didn't represent any correlation with changes in plant biochemical parameters.

Table 1. Monthly changes of polluting gases (ozone, sulfur dioxide and nitrogen dioxide) industrial city (Vigna sinensis L.) in the city of Jeddah, Saudi Arabia.

\begin{tabular}{|c|c|c|c|c|c|}
\hline \multirow{2}{*}{ Site } & \multirow{2}{*}{$\begin{array}{c}\text { Distance } \\
\text { (meter) }\end{array}$} & \multirow{2}{*}{ Month } & \multicolumn{3}{|c|}{ polluting gases conc. (ppb) } \\
\hline & & & $\mathrm{O}_{3}$ & $\mathrm{SO}_{2}$ & $\mathrm{NO}_{2}$ \\
\hline \multirow{20}{*}{ 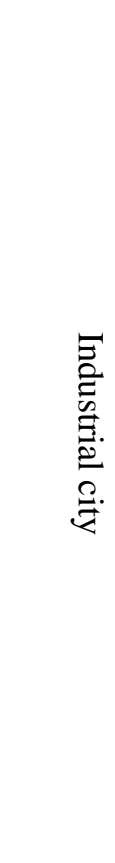 } & \multirow{4}{*}{$1-5$} & January & 71 & 27 & 34 \\
\hline & & February & 73 & 28 & 35 \\
\hline & & March & 78 & 27 & 34 \\
\hline & & April & 82 & 28 & 35 \\
\hline & \multirow{4}{*}{500} & January & 67 & 25 & 33 \\
\hline & & February & 64 & 26 & 34 \\
\hline & & March & 68 & 27 & 33 \\
\hline & & April & 74 & 27 & 34 \\
\hline & \multirow{4}{*}{1000} & January & 61 & 24 & 32 \\
\hline & & February & 60 & 25 & 32 \\
\hline & & March & 64 & 26 & 31 \\
\hline & & April & 69 & 25 & 32 \\
\hline & \multirow{4}{*}{1500} & January & 57 & 22 & 29 \\
\hline & & February & 56 & 24 & 30 \\
\hline & & March & 59 & 25 & 29 \\
\hline & & April & 65 & 25 & 29 \\
\hline & \multirow{4}{*}{2000} & January & 52 & 21 & 29 \\
\hline & & February & 51 & 23 & 28 \\
\hline & & March & 55 & 24 & 29 \\
\hline & & April & 61 & 22 & 28 \\
\hline \multicolumn{3}{|c|}{ Limit global air pollution (ppb) } & $25-30$ & 30 & 35 \\
\hline
\end{tabular}


Table 2. The effect of polluting gases emitted from industrial city in Jeddah on the content of the leaves of fats and protein in plant. Implanted at different distances from industrial city.

\begin{tabular}{|c|c|c|c|}
\hline Site & Distance (meter) & Leaves Fat content (\%) & Leaves Protein Content $(\%)$ \\
\hline \multirow{6}{*}{ 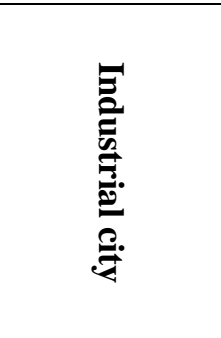 } & Control & 3.64 & 4.67 \\
\hline & $5-1$ & 3.13 & 4.11 \\
\hline & 500 & 3.16 & 4.17 \\
\hline & 1000 & 3.23 & 4.25 \\
\hline & 1500 & 3.25 & 4.32 \\
\hline & 2000 & 3.35 & 4.40 \\
\hline L.S.D $\quad(0.05)$ & & 0.50 & 0.191 \\
\hline
\end{tabular}

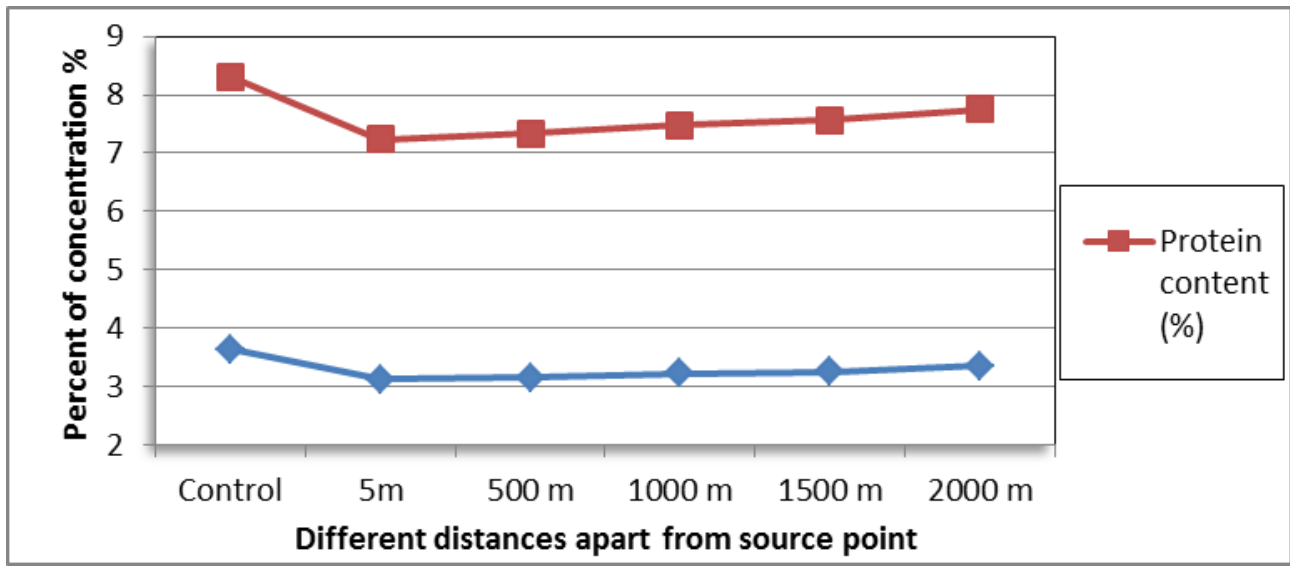

Figure 1. Show the variation in protein and fats content inside the plant (Vigna sinensis L.) in industrial city in Jeddah, Saudi Arabia

Table 3. Statistical analysis for some minerals.

\begin{tabular}{|c|c|c|c|c|c|}
\hline Statistical parameters & Fat content(\%) & protein content $(\%)$ & $\mathrm{O}_{3} \mathrm{ppb}$ & $\mathrm{SO}_{2} \mathrm{ppb}$ & $\mathrm{NO}_{2} \mathrm{ppb}$ \\
\hline Mean & 1.057 & 4.320 & 58.625 & 25.875 & 32.083 \\
\hline Standard Error & 0.067 & 0.082 & 6.463 & 1.087 & 1.116 \\
\hline Median & 1.020 & 4.285 & 61.375 & 25.625 & 32.625 \\
\hline Standard Deviation & 0.165 & 0.200 & 15.831 & 2.663 & 2.733 \\
\hline Minimum & 0.880 & 4.110 & 30.000 & 22.500 & 28.500 \\
\hline Maximum & 1.340 & 4.670 & 76.000 & 30.000 & 35.000 \\
\hline Sum & 6.340 & 25.920 & 351.750 & 155.250 & 192.500 \\
\hline
\end{tabular}

Table 4. Correlation coefficient for plant fats and protein with gaseous pollutants

\begin{tabular}{|l|r|r|r|r|r|}
\hline & Fat content & protein content & \multicolumn{1}{|c|}{$\mathrm{O}_{3}$} & $\mathrm{SO}_{2}$ & $\mathrm{NO}_{2}$ \\
\hline Fat content & 1 & & & & \\
\hline protein content & 0.998111 & 1 & & & \\
\hline $\mathrm{O}_{3}$ & -0.99044 & -0.99468 & 1 & & \\
\hline $\mathrm{SO}_{2}$ & 0.285149 & 0.314133 & -0.3728 & 1 & \\
\hline $\mathrm{NO}_{2}$ & -0.01033 & 0.01371 & -0.08033 & 0.939498 & 1 \\
\hline
\end{tabular}




\section{Discussion}

In this research study the effect of gaseous air pollutants (ozone, sulfur dioxide and nitrogen dioxide) emitted from (Table 4) Correlation coefficient for plant fats and protein with gaseous pollutants on the plant Vigna sinensis L. And determine the five distances $(1-5,500$, 1000, 1500 and 2000 meters) and the reason for conducting this study is to identify concentrations of gaseous air pollutants emitted from industrial city in Jeddah and estimate its harmful effects on protein content and fatty, where results indicate that the concentration of ozone gas exceeded the allowable limit of global air pollution in this gas a $25-30 \mathrm{ppb}$, while the concentration of sulfur dioxide did not exceed the allowable limit of global air pollution which is $30 \mathrm{ppb}$, as well as the gas concentration of nitrogen dioxide did not exceed the allowable limit global air pollution in this gas, which ppb 35 (Castnet 2004). The results showed no difference in the content of the leaves of protein and fat between distances under study, where the differences were statistically significant and may be the low protein content and fatty plant Vigna sinensis L. at distances (1-5, 500, 1000, 1500 meters) compared with the proportion of protein content and fatty at the distance (2000 meters) due to the high concentration of polluting gases in the closer to the source of contamination. This result is consistent with the (Matousel et al. 2005) in his study on Vignara diata L. In order to evaluate the effect of high ozone found where low protein content of $9.8 \%$, also found (Brunschon-Harti et al. 1995) the same result in the bean Phaseolus vulgaris L. It also agrees with what referred to (Cross et al. 1998) that ozone damage proteins and lipids in the cell membrane. As a result of this study supports findings of (Plessl et al. 2007) and (Vorne et al. 2002) in the leaves of potato Solanum tuberosum L. That increasing the concentration of ozone led to a reduction in the content of protein and fat. This result is consistent with findings of (BouJoude et al. 2008) in his study on soybean Glycine max L. It was found that the high ozone led to a decline in the proportion of protein and fat. As mentioned researchers (Devlin and Wiseham, 1998) found that, the difference in metabolic products to members of the communities affected by plant environmental factors and different geographical locations. Exposure to ozone immediately creates an oxidizing environment in plant tissues and triggers an array of cellular responses, including the accumulation of antioxidants, elicitation of pathogenesis-related proteins, deposition of phenols, induction of ethylene synthesis, suppression of primary metabolic activities such as photosynthesis, and eventually cell death (Darrall, 1989; Schraudner et al. 1992; Conklin and Last, 1995; Sharma and Davis, 1997; Tuomainen et al. 1997).

\section{Conclusion}

Exposure to ground level ozone has significant effect on plant biochemical factors especially protein and fats, ground level ozone can change the protein and fats contents in plant while low concentrations of sulfur dioxide and nitrogen dioxide have not any significant impacts on plant metabolism. The proteins and fats plant contents improved as go far from industrial city in Jeddah -Saudi Arabia

\section{Acknowledgment}

We are thankful to the microbiology department in King Saud University for providing the 
laboratory services and encouragement

\section{References}

Agrawal, S.B, Singh, A., \& Rathore, D. (2005). Role of ethylene diurea (EDU) in assessing impact of ozone on Vigna radiata L. plants in a suburban area of Allahabad (India). Chemosphere, 61, 218-228.

Ashmore, M. R. (2005). Assessing the future global impacts of ozone on vegetation. Plant, Cell Environ, 28, 949-964.

BouJaoude, M., Katerji, N., Mastrorilli, M., \& Rana, G. (2008). Analysis of the ozone effect on soybean in the Mediterranean region II. The consequences on growth, yield and water use efficiency. Europ. J. Agronomy, 28, 519-525.

Brunschon-Harti, S., Fangmeier, A., \& Jager, H.J (1995). Effects of ethylene diurea and ozone on the antioxidative systems in beans (Phaseolus vulgaris L.). Environ. Pollut, 90(1), 95-103.

Calatayud, A., Ramirez, J. W., Iglesias, D. J., \& Barreno, E. (2002). Effects of ozone on photosynthetic $\mathrm{CO}_{2}$ exchange, chlorophyll a fluorescence and antioxidant system in lettuce leaves. Physiologia Plantarum, 116, 308-316.

Castagna, A., Nali, C., Ciompi, S., Lorenzini, G., Soldatini, G. F., \& Ranieri, A. (2001). Ozone exposure effects photosynthesis of pumpkin (Cucurbita pepo) plants. New Phytologist, $152,223-229$.

Castnet (Clean Air Status and Trends Network), 2004.

Cerena, M., Bonza, M. C., Harris, R., Sanders, D., \& Michelis, M. I. D. (2006). Abscisic acid stimulates the expression of two isoforms of plasma membrane $\mathrm{Ca}^{+}$-ATPase in rabidopsis thaliana seedlings. Plant Biology, 8, 572-578.

Conklin, P. L., \& Barth, C. (2004). Ascorbic acid, a familiar small molecule intertwined in the response of plants to ozone, pathogens and the onset of senescence. Plant Cell Environ, 27, 959-970.

Conklin, P.L., \& Last, R.L. (1995). Differential accumulation of antioxidant mRNAs in Arabidopsis thaliana exposed to ozone. Plant Physiol, 109, 203-212.

Cross, C.E., Van der A., Vliet, S. Louie, J., Hiele, J., \& Halliwell, B. (1998). Oxidative stress and antioxidants at biosurfaces: plants, skin, and respiratory tract surfaces. Environ. Health Perspectives, 106, 1241-1251.

Darrall, N.M. (1989). The effect of air pollutants on physiological processes in plants. Plant Cell Environ, 12, 1-30.

Degl'Innocenti, E., Guidi, L., \& Soldatini, G. F. (2002). Characterization of the photosynthetic response of tobacco leaves to ozone: $\mathrm{CO}_{2}$ assimilation and chlorophyll fluorescence. J. Plant Physiol, 159, 845-853. 


\section{Macrothink}

Devlin, R., \& Wiseham. F. (1998). Plant physiology D. Van NostrondCo.N.Y.

Evans, N. H., McAnish, M. R., Hetherington, A. M., \& Knight, M. R. (2005). ROS perception in Arabidopsis thaliana: The ozone induced calcium response. Plant J., 41, $615-626$.

Guidi, L., Degl'Innocenti, E., \& Soldatini, G. F. (2002). Assimilation of $\mathrm{CO}_{2}$, enzyme activation and photosynthetic electron transport in bean leaves, as affected by high light and ozone. New Phytologist, 156, 377-388.

Hamwi, M., Mahmoud H. B., \& Al-Mohammad (1999). Environmental and physiological diseases. Directorate books and university publications. Aleppo.

Janik \& Julius. (1985). Horticulture. Translation Gamil Fahim Suriel and others. Dar Al Arabia for publication and distribution, Cairo.

Jones, Jr. (1991). Kjeldahl method for nitrogen determination. Micro-Macro Publishing Inc. Athens, GA, USA.

Klusener, B., Young, J. J., Murata, Y., Allen, G. J., Mori, I. C., Hugouvieux, V., et al. (2002). Convergence of calcium signaling pathways of pathogen elicitors and abscisic acid in Arabidopsis guard cells. Plant Physiol., 130, 2152-2163.

Kollner, B., \& Krause, G. H. M. (2003). Effects of two different ozone exposure regimes on chlorophyll and sucrose content of leaves and yield parameters of sugar beet (Beta vulgaris L.) and rape (Brassica napus L.). Water Air and Soil Pollut., 144, 317-332.

Logan, S.P., \& Naidu, S.L. (2002). Effects of oxidants at the biochemical, cell and physiological levels, with particular reference to ozone. In: Bell, J.N.B., Treshow, M. (Eds.), Air Pollut. Plant Life, 69-88.

Moldau, H. (1999). Ozone detoxification in the mesophyll cell wall during a stimulated oxidative burst, Free Rad. Res., 31, 19-24.

Nussbaum, S., Geissmann, M., Eggenberg, P., Strasser, R. J., \& Fuhrer, J. (2001). Ozone sensitivity in herbaceous species as assessed by direct and modulated chlorophyll fluorescence techniques. J. Plant Physiol., 158, 757-766.

Ohara, T., Akimoto, H., Kurokawa, J., Horii, N., Yamaji, K., Yan, X. et al. (2007). An Asian emission inventory of anthropogenic emission sources for the period 1980-2020. Atmospheric Chem. Physics, 7, 4419-4444.

Pasqualini, S., Della Torre, G., Ferraniti, F., Ederli, L., Piccioni, C., Reale, L., et al. (2002). Salicylic acid modulates ozone induced hypersensitive cell death in tobacco plants. Physiol. Planta., 115, 204-212.

Pell, E.J., Schlagnhaufer, C.D., \& Arteca, R.N. (1997). Ozone induced oxidant stress: Mechanisms of action and reaction. Physiol. Plant., 100, 264-273.

Pleijel, H., Danielsson, H., Ojanpera, K., De Temmermann, L., Hogy, P., Badiani, M., et al. 


\section{Macrothink}

Environmental Management and Sustainable Development

ISSN 2164-7682

2014, Vol. 3, No. 1

(2004). Relationships between ozone exposure and yield loss in European wheat and potato-Acomparison of concentration and flux based exposure indices. Atmospheric Environ., 38, 2259-2269.

Plessl, M, E., Elstner, F., Rennenberg, H., Habermeyer, \& J. Heiser, I. (2007). Influence of elevated $\mathrm{CO}_{2}$ and ozone concentrations on late blight resistance and growth of potato plants. Environ. Exp. Bot., 60, 447-457.

Prather, M., Ehhalt, D., \& Dentener, F. (2001). Atmospheric chemistry and greenhouse gases. In J. J. Houghton, Y. Ding, D. J. Griggs, M. Noguer, P. J. an der Linden, X. Dai, et al. (Eds.), Climate change 2001. The scientif ic basis, contribution to working group I to the third assessment report of the intergovernmental panel on climate change (pp. 239-287). Cambridge:Cambridge University Press.

Sandermann, H., Ernst, D., Heller, W., \& Langebartels, C. (1998). Ozone, An abiotic elicitor of plant defense reactions. Trends Plant Sci., 3, 47-50.

Schraudner, M., Ernst, D., Langebartels, C., \& Sandermann, H. (1992). Biochemical responses to ozone. III. Activation of the defense-related proteins _-1,3-glucanase and chitinase in tobacco leaves. Plant Physiol., 99, 1321-1328.

Sharma, Y.K., \& Davis, K.R. (1997). The effects of ozone on antioxidant responses in plants. Free Radical Biol. Med., 23, 480-488.

Standard Arabia. (1982). \# 547. Saudi Organization for Standardization and Metrology, Riyadh, Saudi Arabia.

Tiwari, S., Rai, R., \& Agrawal, M. (2008). Annual and seasonal variations in tropospheric ozone concentrations around Varanasi. Int. J. Remote Sensing, 29, 4499-4514.

Tuomainen, J., Betz, C., Kangasjärvi, J., Ernst, D., Yin, Z., Langebartels, C., \& Sandermann, H. (1997). Ozone induction of ethylene emission in tomato plants: Regulation by differential transcript accumulation for the biosynthetic enzymes. Plant J., 12, 1151-1162.

Vorne, V., Ojanpera, K., De Temmerman, L, Bindi, M., Högy, P., Jones, M.B., Lawson T., \& Persson, F, K. (2002). Effects of elevated carbon dioxide and ozone on potato tuber quality in the European multiple-site experiment 'CHIP project'. Europ. J. Agron, 17, 369-381.

\section{Copyright Disclaimer}

Copyright reserved by the author(s).

This article is an open-access article distributed under the terms and conditions of the Creative Commons Attribution license (http://creativecommons.org/licenses/by/3.0/). 